\title{
Making English grammar meaningful to non grammarians: the English Verb and some effective classroom strategies to be employed by teachers
}

\author{
${ }^{1}$ Ebibi, Johnson Ojeka, ${ }^{2}$ Nnaji, Patience Onyinyechi , ${ }^{3}$ Ebibi, Rosemary Abeyi \\ ${ }^{I}$ Department of Remedial Sciences University of Jos NIGERIA. \\ ${ }^{2}$ Dept of Television Journalism NTA Television College(an affiliate of Ahmadu Bello University, Zaria, \\ NIGERIA \\ ${ }^{3}$ Erdoo Memorial Nursery and Primary school Makurdi Benue State NIGERIA.
}

\begin{abstract}
The English Language is assuming increasing roles in Nigeria and globally thus the need to make its grammar more meaningful and more result-oriented to greater number of Nigerians and other peoples of the world has become imperative. This need is even more urgent in Nigerian context given the fact that English is the language of intra and inter-ethnic communication apart from its official status and functions in Nigeria's economic, legal, technological, educational, socio-political life. Just as English is central to Nigeria's progress so also is the verb to English. The verb is an obligatory element in English because without it no sensible sentence can be made in the language. The English verb is as wide as human speech hence it will be impossible to explain it in detail in a single paper of this nature. The descriptive research design was used to discuss the verb paying particular attention to its auxiliaries and contractions. Some approaches and teaching strategies that would make the learning of this obligatory element of all English sentences more meaningful and resultoriented within and outside the classroom situations were also suggested.
\end{abstract}

Keywords: English grammar, effective classroom strategies, grammarians, non grammarians, verb.

\section{Introduction}

The importance of English grammar cannot be overstressed thus Murthy (2007) says that 'as far as English language is concerned, the grammar has greater importance and significance in practical life'. He further opines that 'unless we have mastered grammar, we do or cannot speak or write English correctly. Besides, English language is closely related and associated to or with grammar and it is entirely based on grammar. English is very much controlled, conditioned and regulated by grammar'. Murthy defines grammar as 'a systematic study of scientific method which provides us information and guidance necessary to learn a language'. American Heritage Dictionary of English (2009) defines grammar as a branch of linguistics that deals with syntax and morphology sometimes also phonology and semantics of a language. It further defines grammar as the use of language with regards to its correctness or social propriety, especially in syntax. Suffice it to say that while English is controlled and regulated by its grammar, grammar is in turn controlled and regulated by the verb. The verb is the heartbeat of English grammar no sensible sentence can be made in English without a verb.

The verb has been variously defined as a part of the sentence that expresses what a subject does in a sentence as well as what happens to the object where there is one. A verb also expresses what the subject feels, experiences or thinks. At times, it expresses a state of being. According to Murthy (2007) a verb is a word used to express action or condition (a state of being) or existence.

Ukwuegbu, Okoro, Idris, Okebukola, Owokade, and Okebukola (2004) define a verb as a word or group of words that denotes an action or state of being. They opine that the action can be physical (e.g. write, sing, shout) or mental (e.g. think, hope, expect); the most frequently used state of being verb according to them is ' $\mathrm{Be}$ ' with its different forms. According to them, verbs are generally classified into lexical (main) and auxiliary or helping verbs. Lexical verbs are further grouped into regular and irregular, transitive and intransitive, linking and none linking, stative and dynamic, simply/complex verbs.

The auxiliary verbs are the most intricate and complicated of all the kinds of verbs in English and they are also at the centre of contraction which seems confusing to non grammarians. Quirk and Greenbaum (1989) state that auxiliary verbs are grouped into two major classes namely:

\section{- $\quad$ The primary auxiliary}

- $\quad$ The modal auxiliary verbs.

The primary auxiliary verbs are:

Be, Do, have and their forms.

Be: am, is, are---- present 


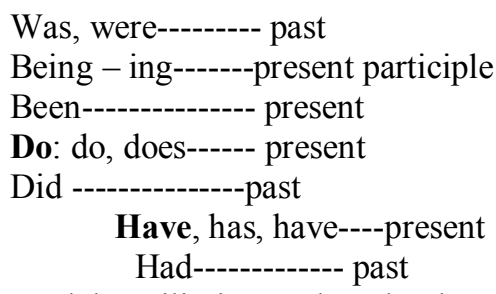

Modal auxiliaries on the other hand are:

$\begin{array}{lll}\text { Can/could } & \text { Will/would } & \\ \text { Shall/should } & \text { ought to } & \\ \text { Dare } & \text { May/might } & \\ \text { Must } & \text { Used to } & \text { Need }\end{array}$

They explained that one factor of distinction between the primary auxiliary verbs and the modal auxiliary verbs is, while the former can be used as both main and auxiliary verbs, the latter can only function in a sentence as auxiliaries. In other words, the primary auxiliary verbs can function as the main verb elements in a sentence and can also function as an auxiliary in another.

For example:

James is a student. is here is a main verb

James is reading English. is here, is an auxiliary while reading is the main verb.

Obasa, Alamu, Kunle and Giwa (1995) say that a verb is a doing word and that it expresses the action of the doer (i.e. a noun or pronoun). They stressed that is the most important element in a sentence as it links subjects and predicates together.

Examples: I sing every day.

Fatima writes well

The principal will see you tomorrow.

They classify verbs into regular verbs:

These are verbs which form their past and participle forms by adding 'ed' to the 'present' form.

a) Example:

$\begin{array}{lll}\text { Present tense, } & \text { past tense, } & \text { past participle } \\ \text { Stop } & \text { stopped } & \text { stopped } \\ \text { Add } & \text { added } & \text { added }\end{array}$

b) Irregular verbs:-

These form their past and participle forms in different ways. E.g.:-

$\begin{array}{lll}\text { Write } & \text { wrote } & \text { written } \\ \text { Do } & \text { did } & \text { done } \\ \text { Find } & \text { found } & \text { found }\end{array}$

\section{The tense}

According to Enighe and Afangideh (2001) Tense is a property of the verb, that is, it occurs only in verbs. Although it is usual to talk about the past, present, future and other tenses, it should be noted that tense is not exactly the same thing as time. Rather, tense refers to the change that takes place in the form of verb to indicate time. Enighe and Afangideh stressed that, on the basis of the changes that take place in the form of the verb to indicate time, only two tenses, namely the present and the past can be identified. However, English has different aspects of the present and the past as well as different ways of indicating the future.

Example:

I see a bird on the fence.

I saw a bird on the fence yesterday.

I shall be seeing a number of birds when I go to the woods.

Each of the above sentences implies one tense or the other indicating the time of action.

The present tense: according to them, except in the case of the verb 'be' the only change that takes place in the form of the verb to indicate the present tense occurs when the verb agrees with a third person singular subject as exemplified in the sentences below:

\section{Singular}

i. $\quad$ I sleep, wake and eat

ii. $\quad$ You sleep, wake and eat

iii. He sleeps wakes and eats

\section{plural}

We sleep, wake and eat

You sleep, wake and eat

They sleep, wake and eat.

The tense is said to be simple present when the verb element that indicates the present is a singular word.

The simple present tense is used to 
(a) express habitual action. e.g Oheha always drinks after meals.

(b) express what is fixed. E.g. The bus arrives at 9.am.

(c) express eternal truths: God is almighty (64).

Banjo, Ayodele, and Ndahi, (1997), say that the verb plays an important role in helping us to communicate with each other and that without a verb, an utterance would be rendered meaningless. They stressed that a verb therefore acts as the 'nerve centre' of any utterance. In the following sentences; the verb are underlined.

(i) Miracle works at the factory

(ii) Emeka was a medical doctor

(iii) Iranyohe is young and beautiful.

(iv) My mother used to go to Lagos every year.

Banjo, Ayodele, and Ndahi explain verb expresses the idea of time, tense and mood in a sentence. Sentences (1) and (3) refer to present time (and so are expressed in the present tense): while (2) and (4) refer to past time (and are therefore expressed in the past tense).

Like other Linguists, they emphasized that a verb occupies a typical position in the sentence. In statements, it normally occurs after the subject, as in the four examples above. However, in questions, it may occur before the subject. For instance;

(5) Can I come tomorrow?

(6) Did Gubia clean the room?

They offered the following explanations: In these sentences, the first part of the verb phase (the auxiliary) comes before the subject, while the second part (lexical verb) follows the subject; in the tag questions, the verb occupies its usual position after the subject in the tag. For instance:

(7) The children will vacate tomorrow, won't they?

In commands the verb may appear alone, that is, by itself, as in

(8) come!

(9) jump!

The verb phase expresses an action performed, a state or process in a sentence. For instance, the verbs in examples (10) - (12) express action.

(10) The horse jumped over the tense

(11) The woman beat the children who came late.

(12) The national football team played well.

However, in $13-15$ the idea expressed is that of process; the verbs suggest processes that are taking place.

The children are growing into adolescents.

The milk is turning sour

The leader is getting tired

Other verbs simply indicate states - the state of being a person, or the state of an object or thing. For example;

The girls are happy.

The fruit is fresh

The children dislike their step mother.

Verbs in this category includes; 'see' 'hear,' 'think', 'trust', 'hope', 'appreciate', 'love', 'understand', such verbs are not normally found in the -ing form. For instance, it is wrong to say: -

(9) I am seeing you. (If you mean to say that you can see me).

\section{Forms of verbs}

According to Banjo et al (1997), English verbs can be divided into regular and irregular depending on the forms they take.

\section{Regular verbs}

According to them, regular verbs have the following forms:

\begin{tabular}{|l|l|l|l|l|}
\hline Simple present & $\mathbf{3}^{\text {rd }}$ person singular & Present participle & Simple past & Past participle \\
\hline Save & saves & saving & saved & Saved \\
\hline Talk & talks & talking & talked & Talked \\
\hline Receive & receives & receiving & received & Believed \\
\hline Believe & believes & believing & believed & Believed \\
\hline Work & works & working & worked & Worked \\
\hline
\end{tabular}




\section{Types of verbs}

It is possible to distinguish several sub-groups of verbs.

They may distinguish lexical (main) and auxiliary verbs, transitive and intransitive verbs, linking and no linking verbs, finite and non finite verbs and plural verbs. (Banjo, Ayodele and Ndahi 1997).

\section{Lexical and auxiliary verbs}

Lexical (or main) verbs can stand alone as the verb elements in sentences. For example:

The young woman danced till down.

Bala did his home work yesterday.

The auxiliary verb is a helping verb. It appears with a main (lexical) verb as in :

They will clear the farm next week.

Can we use the library in the evening?

In these examples will and can are auxiliaries while clear and use are main verbs.

There may be several auxiliaries in a sentence as in the following examples:

They have been playing all night

I would have done it another way if I knew how.

In the first sentence may have been are auxiliaries while playing is the main verb.

\section{Transitive and intransitive verbs}

Transitive verbs do not take objects.

Example

The goat ate the corn.

My grandmother has cultivated the farm.

The teacher gave the class a test,

In all these sentences the verbs take objects and are therefore transitive verbs.

The following verbs are intransitive verbs.

Flourish plays very well.

Segun drinks heavily.

They are running.

As we can see, there are no objects in the sentences.

Some verbs may be used both transitively and intransitively. For example: eat and play fall into this category.

\section{Linking and non linking verbs}

A distinction can also be made between linking and non linking verbs. A linking verb is one that occurs between a nominal (noun, pronoun etc) and an adjectival: example:

The man looked hungry

The children seemed worried.

Sometimes it may appear between two nominals.

Examples:

The man is my father.

Audu became a doctor.

Banjo, Ayodele and Ndahi (1997) note that there can be two nominals with the same referent that is, they refer to one and the same person. In the first sentence 'the man' similarly, in the second sentence 'Audu' and 'a doctor' refers to the same person. Some common linking verbs are: 'be', 'seem', 'become', appear', 'feel', taste' 'smell', 'sound', 'grow', prove', 'remain', 'turn', 'go', 'keep', 'look', (114 - 116).

Asudo, and Marsh, (1982) say that verbs are words of doing, being, having, saying or thinking. They usually involve action by the subject of the sentence:

I remember

Birds fly.

She believes.

The government decides.

Verb can also express circumstances

Examples:

Sam seems happy today.

Our neighbor became ill.

They further explained that because verbs express action they often have an effect upon something, or somebody, and this thing or person is called the object of the verb.

Example: 
She dropped the plate (verb dropped; object plate) the teacher marks my book (verb book)

Father crossed the road. (Verb crossed: object road).

- $\quad$ I recognized the girl (verb recognized, object girl) late need to note that not all verbs take objects. (12).

\section{The Morphology of the Verb}

According to Eka (2004) the term verb can be explained traditionally, formally and functionally. Traditionally: A verb is a doing or an action word. He pointed out that this traditional explication leaves a lot unsaid, for there are many verbs which do not do or act in any straight forward way as this definition suggests. For example, the verbs seem and have do not do or act in any factual sense.

Formally: a verb is a grammatical element that is capable of showing a large number of morphological contracts explicable in terms of tense (time reference): aspect, voice, mood, person and number. Tense, as shown above relates to time reference.

Accordingly, Eka stresses that, it operates in relation to the verb. From the view point of English morphology (that is changes which can occur in the shape of English words) two types of tense are often recognized: past and non past (or past and present). From the standpoint of time reference, three types are generally isolated: present, past, future. But if we consider time reference as a systemic angle, then we notice a lot more complexity one time reference shading into the other (Eka, 2004).

Thus we can have:

I past in past: had taken.

II past in present; has taken.

Eka further states that it is possible to have up to a maximum of five combinations: present in; past in; future in; past in; present: has been going to have been taking and that aspect traditionally relates to tense and expresses the perfective and progressive. The former usually shown by the presence of has/have /had before the lexical verbs had taken (past perfect)" has taken (present perfect). The latter is usually shown by presence of ing form

- $\quad$ Is taking, was taking.

- $\quad$ Voice: relates to two contrasts:

- $\quad$ active

- $\quad$ Passive

Examples:

(i) Peter cut down a tree (Active voice).

(ii) A tree was cut down by peter, (passive voice)

Mood: refers to a set of syntactic and semantic contrasts signaled by certain forms of verbs. Such contrasts could show the indicative mood (generally unmarked) and the imperative mood (often marked).

The indicative mood may be declarative as in:

(i) Michael is my friend it could be interrogative as in

(ii) Is Michael friend?

(iii) Who is Michael's friend? (103).

Example 4 is a polar question, one requiring the answer "yes" or "No"

Example 5 is a non polar question, one that seeks for information. Imperative mood relates to commands but more specifically to altitude of the speaker towards the content of the utterance.

There are two types of imperatives

- Jussive

- $\quad$ Non jussive

(i) Jussive Imperatives are those verbs which Include or Exclude the speaker, and one that involves a tag question

(ii) $\quad-$ A question added after a main clause.

Examples:

6. Let's read.

This includes the speaker.

7. You read.

8. Read.

(These two (7\&8) do not include the speaker).

9. Read up for your examination, won't you? (This involves a tag question).

Then non-Jussive imperatives are of two types: one volitive involving strong desire or even prayer and the other optative - involving a suggestion often to get someone to do something. 
The following are examples.

(10) May our nation no longer experience a civil war.

(This is volitive).

(11) Let Miss Gold see the Head of English.

(12) Someone put up this notice.

(13) These two (11 and 12) are optative with person, three choices are involved:

1 st person-I, me, we, us etc

$2^{\text {nd }}$ person - you, your, yours etc.

$3^{\text {rd }}$ person - he, him, they etc.

These are used with specific view forms.

\section{The Syntactic Parameters for Differentiating between Auxiliary and Lexical Verbs \\ Test of negation}

According to Eka, (2004) a lexical verb is a main verb; it provides the major information in an utterance. The following are example of lexical verbs:

Sing, dance, play, plan, reason.

An auxiliary verb is a subordinate, a supporting or helping verb:

In English three kinds of auxiliaries: indentified.

The central) or main auxiliaries:

The modal auxiliaries

The marginal, (peripheral or semi- auxiliaries.

Examples of central auxiliaries are: do, be and have.

Examples of modal auxiliaries are: can/could, may/might, shall/ should; will/would; must, ought to.

Examples of marginal auxiliaries are: used to, dare, and need.

These three are marginal because they share some, but not all, the characteristics of auxiliary verbs.

Generally lexical verbs differ from auxiliaries as shown above;

The lexical verbs provide the main information. The lexical verbs provide support. Also auxiliary verbs can undergo negative contraction. For instance we do not say Jane sing not, dance n't or playn't. Auxiliary verbs differ from lexical ones in a third way: the auxiliaries can be used with subject inversion. For instance we can say

He is coming.

Is he coming?

She has gone to school

Has she gone to school?

In contrast, we can say.

Okon plays football

But we do not normally say plays Okon football.

Quite often the auxiliary verbs go along with their lexical counterparts as shown above where is and has are auxiliary verbs and coming and gone are lexical to show this kind of association.

I have answered the phone twice already.

He accepted that $\mathrm{J}$ could borrow his book.

In these examples have is a major auxiliary and borrow are lexical verbs.

As already mentioned, the central members of the auxiliary subgroup of verbs are do, be and have. However do and have are quite flexible.

- $\quad$ They may function as lexical or auxiliary verbs.

- $\quad$ They may be used with the indicator of negation as well as without it.

- $\quad$ The indicator of negation when it occurs may be contracted or non contracted.

\section{Test of Polarity}

Test of polarity focuses on the "yes-ness" or "no-ness" of an expression. In this case the auxiliary verb is sometimes used for emphasis and to state or express the positive or negative part of an expression.

\section{Test of inversion}

In a normal sentence, the subject should come before the verb but with inversion, the position changes with the auxiliary verb appearing before the subject. For instance,

You will come tomorrow. The subject you comes before the verb will come.

Will you come tomorrow? The modal auxiliary comes before the subject. 


\section{Test of substitution}

In a situation where there are two independent clauses, it is only the auxiliary verb that can be used to substitute for the second clause. E.g.

John came here yesterday but Mary did not come here yesterday.

John came here yesterday but Mary did not. (Eka, 2004)

\section{Conclusion}

Because of the integral role English and by extension English grammar plays in the world, several studies have been carried out and are being undertaken to find out how best to make the acquisition of English and some other languages better and result-oriented. The outcome of these studies is emergence of the communicative language teaching approach in the 1970s. It should be pointed out that prior to this period, the audio-lingual method and a few others were the most prevalent methods teachers of English employed. These methods have dominated our classrooms for so long that the call for change to other approaches has become an anathema. This is perhaps because most of our language teachers were taught using these methods. By way of explanation, Wikipedia, the free encyclopedia (2014) says:

The audio-lingual method, Army Method, or New Key is a style of teaching used in teaching foreign languages. It is based on behaviorist theory, which professes that certain traits of living things, and in this case humans, could be trained through a system of reinforcement - correct use of a trait would receive positive feedback while incorrect use of that trait would receive negative feedback.

The communicative language teaching (CTL) approach which is one of the latest and most advocated approaches to language teaching is based on the idea that learning language successfully comes through having to communicate real meaning. When learners are involved in real communication, their natural strategies for language acquisition will be used, and this will allow them to learn to use the language. For instance, Practicing question forms by asking learners to find out personal information about their colleagues is an example of the communicative approach as it involves meaningful communication (Wikipedia, the free encyclopedia, 2014) Not a highly structured method of teaching rather a broad assemblage of ideas from a range of sources which have come to be accepted as 'good practice' by many contemporary teachers. A critical look at the two schools of thought reveals that both strategies have something to offer. Consequently, the position of this paper is that there should be a synergy between audio lingual with other methods and the communicative approach so that the highly structured nature of the audio lingual with other language teaching methods will complement the unstructured disposition of the communicative language approach.

\section{References}

[1]. Akindele, F. \& Adegbite, W. (2005). The sociology and politics of present day English: An introduction. Ibadan: O.A.U press.

[2]. American Heritage Dictionary of the English Language (2000). Fourth Edition, New Jersey:Houghton Mifflin Company.

[3]. Asudo, J. O. \& Marsh, L.G. (2001). Forty Lessons and excises in grammar and language. Ibadan: Spectrum Books Ltd.

[4]. Banjo, S. Ayodele S. \& Ndahi, K. (1997). Exam focus English Language for

[5]. SSCE and JME. Ibadan: Ibadan University Press Plc.

[6]. Eka, D. (2004) Elements of grammar and mechanics of English language

[7]. Uyo: Samut (Nig) Ltd.

[8]. Enighe J. \& Afangideh, E. (2001). A guide to basic English. Jos: LECAPS (Nig)

[9]. Ltd

[10]. Obasa, A.O., Alamu, S. \& Giwa, I. (1995). English language for senior secondary school

[11]. Examination. Ibadan: Spectrum Books Ltd.

[12]. Olu Tomori, S.H. (1990) Morphology and syntax of present day English: An introduction. London: Heinemann.

[13]. Murthy, J. D. Contemporary English grammar: Reference and practice through real English. Lagos: Bookmaster

[14]. Quirk, R. and Greenbaum, S. (1989). A University Grammar of English

[15]. Hong Kong: Long Group (FE) Ltd.

[16]. Wikipedia, the free encyclopedia, (2014). Communicative language teaching. Retrieved March 10, 2014.

[17]. Williams, D. (2004). English language teaching: An integrated approach. Ibadan: Spectrum Books Limited. 